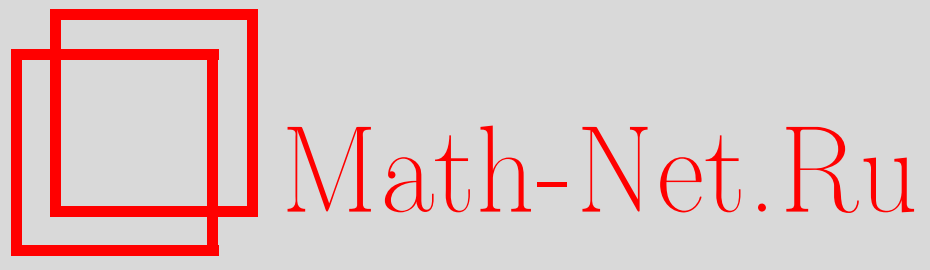

Вадим Роландович Фаталов, Теория вероятн. и ее примен., 2019, том 64, выпуск 4, 824

DOI: https://doi.org/10.4213/tvp5372

Использование Общероссийского математического портала Math-Net.Ru подразумевает, что вы прочитали и согласны с пользовательским соглашением http://www . mathnet.ru/rus/agreement

Параметры загрузки:

IP: 3.93 .64 .190

26 апреля 2023 г., 17:08:55

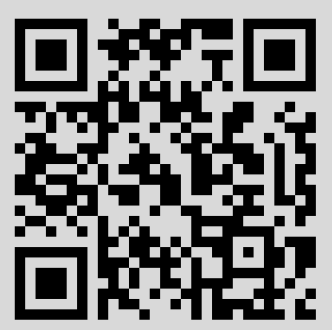




\section{ВАДИМ РОЛАНДОВИЧ ФАТАЛОВ}

4 июня 2019 года после тяжелой продолжительной болезни скончался ведущий научный сотрудник лаборатории теории вероятностей механико-математического факультета Московского государственного университета им. М. В. Ломоносова Вадим Роландович Фаталов.

Вадим Роландович родился 18 мая 1957 г. в Кировабаде, ныне Гянджа, Азербайджан, в семье военнослужащего, участника Великой Отечественной войны. В 1974 г. он окончил физико-математическую школу в Баку, и в том же году поступил на механико-математический факультет Ереванского государственного университета. Будучи студентом 4-го курса, принял участие в зимней школе по теории вероятностей в Цахкадзоре, где заинтересовался тематикой работ кафедры теории вероятностей Московского государственного университета. С 1979 г. обучался в аспирантуре механико-математического факультета МГУ, на кафедре теории вероятностей.

Уже с первых научных работ определился интерес В. Р. Фаталова к асимптотическим методам функционального анализа и приложениям этих методов в теории случайных процессов. Этот интерес был заявлен и существенно развит в первой большой и широко цитируемой работе "Метод Лапласа для вероятностных мер в банаховых пространствах" (Успехи математических наук, 50:6(306) (1995), 57-150). Далее Вадим Роландович сосредоточился на трех направлениях развития асимптотических методов исследования распределений различных норм траекторий случайных процессов и полей, в первую очередь на исследовании вероятностей малых уклонений траекторий, а также вероятностей умеренных и больших уклонений. Таким образом, метод Лапласа, исторически появившийся для асимптотического анализа поведения одномерных интегралов, зависящих от бесконечно растущего параметра, В. Р. Фаталов превратил в универсальный метод асимптотического исследования интегралов в бесконечномерных функциональных пространствах. Развитые им методы исследования асимптотического поведения малых уклонений траекторий марковских и гауссовских случайных процессов в гильбертовом и банаховых пространствах безусловно являются пионерскими, они широко цитируются, и стали одним из основных инструментов исследования в этой области, темой нескольких диссертаций. Особое внимание В. Р. Фаталов уделял конкретным моделям из различных областей приложений. Им получены выдающиеся результаты о малых, умеренных и больших уклонениях мер и процессов Боголюбова, процессов Бесселя, векторных процессов Орнштейна-Уленбека, винеровских процессов и полей, дробных (фрактальных) гауссовских процессов и полей, многих других. Вадим Роландович опубликовал по этой тематике более 30 научных работ.

В. Р. Фаталов постоянно работал в различных приложениях теории вероятностей. Так, он внес значительный вклад в развитие теории расчета высокоточных и высокоскоростных подшипников качения.

Светлая память о Вадиме Роландовиче навсегда сохранится в наших сердцах.

Редколлегия журнала, Кафедра и лаборатория теории вероятностей механико-математического факультета МГУ им. М. В. Ломоносова 